\title{
SCIEnTific Article \\ Luminosity levels and substrates composition on Bermuda Grass development
}

\author{
João André do Amaral ${ }^{1}$, Maximiliano Kawahata Pagliarini2 ${ }^{*}$, Kuniko Iwamoto Haga ${ }^{3}$, Regina Maria Monteiro de Castilho ${ }^{4}$
}

\begin{abstract}
Turfgrass is a fundamental part in sports fields' composition. Some aspects should be taken into account in the choosing species process, such as turfgrass use (trampling tolerance), turfgrass management, physical-chemical soil conditions and shade tolerance. With accomplishment of sporting events in Brazil, there was requirement for football arenas reform and modernization. Among architecture alterations, coverings implantation was noticed, resulting luminosity reduction affecting turfgrass development. Therefore, the objective of this work was to evaluate the influence of luminosity and substrates on Bermuda grass (Cynodon dactylon $\mathrm{x}$ C. transvaalensis) development. The experiment was conducted in a $5 \mathrm{x} 4$ factorial scheme (substrates x luminosities), in completely randomized design with 20 treatments and 3 replicates. The substrates were: S1 = Soil, S2 = Soil + sand (2:1), S3 $=$ Soil + organic matter $(1: 1), \mathrm{S} 4=$ Soil + organic matter + sand $(2: 1: 1)$ and S5 = organic matter + sand $(3: 1)$, in four luminosity conditions: full sun, $30 \%, 50 \%$ and $80 \%$ of shading for six months. We evaluated substrates fertility composition, solar radiation, grass height and fresh and dry mass. Shading interfered on Bermuda grass development, which tolerates intermediate shading $(30 \%$ and $50 \%$ ). Substrates containing the highest levels of organic matter submitted to shading had impaired turfgrass performance.

Keywords: Cynodon dactylon x C. transvaalensis, Turfgrass, shade tolerance, sport fields, organic matter.
\end{abstract}

\section{Resumo}

Níveis de luminosidade e composição de substratos no desenvolvimento de grama bermuda

Gramado é parte fundamental na composição de campos esportivos. Alguns aspectos devem ser levados em consideração no processo de escolha da espécie a ser utilizada, como a utilização do gramado (tolerância ao pisoteio), manejo do gramado, condições físico-químicas do solo e tolerância ao sombreamento. Com a realização de eventos esportivos no Brasil, houve a necessidade de reformas e modernizações das arenas de futebol. Dentre as alterações na arquitetura está a implantação de coberturas nos estádios, o que resultou em uma redução da luminosidade, afetando o desenvolvimento normal do gramado. Objetivou-se com o experimento avaliar a influência da luminosidade e de substratos no desenvolvimento de grama bermuda (Cynodon dactylon $\mathrm{x}$ C. transvaalensis). Foi conduzido em esquema fatorial $5 \mathrm{x} 4$ (substratos $\mathrm{x}$ luminosidades), em delineamento inteiramente casualizado com 20 tratamentos e 3 repetições. Os substratos foram: S1 = Solo, S2 = Solo + areia $(2: 1), \mathrm{S} 3=$ Solo + matéria orgânica (1:1), S4 = Solo + matéria orgânica + areia (2:1:1) e S5 = Matéria orgânica + areia (3:1), em quatro condições de luminosidade: pleno sol, $30 \%, 50 \%$ e $80 \%$ de sombreamento, durante seis meses. Foram avaliados: composição da fertilidade dos substratos, radiação solar, altura de grama a massa fresca e massa seca. O sombreamento interferiu no pleno desempenho da grama bermuda, sendo que esta tolera sombreamento intermediário (30\% e 50\%). Substratos que continham maiores teores de matéria orgânica submetidos ao sombreamento tiveram o desempenho prejudicado.

Palavras-chave: Cynodon dactylon x C. transvaalensis, Gramado, tolerância ao sombreamento, campos esportivos, matéria orgânica.

\footnotetext{
${ }^{1}$ Prefeitura Municipal de São José do Rio Preto, São José do Rio Preto-SP, Brazil

${ }^{2}$ Universidade Federal da Grande Dourados, Fazenda Experimental de Ciências Agrárias, Dourados-MS, Brazil *Corresponding author: mpagliarini@ufgd.edu.br

${ }^{3}$ Universidade Estadual Paulista "Júlio de Mesquita Filho", Departamento de Biologia e Zootecnia, Faculdade de Engenharia, Ilha Solteira-SP, Brazil.

${ }^{4}$ Universidade Estadual Paulista “Júlio de Mesquita Filho”, Departamento de Fitotecnia, Tecnologia de Alimentos e Sócio-Economia, Faculdade de Engenharia, Ilha Solteira-SP, Brazil
} 


\section{Introduction}

Grass is a generic term, encompassing several species of plants with prostrate growth habit and belonged to Poaceae family. Some species are widely used as soil cover for various purposes such as gardens, parks, slope protection and used in sports fields such as football, golf, tennis, polo. The multiplication process is by seed, transplant or by clumps division and should be used in sunny places. In addition to this, its main characteristic should be trampling tolerance (Demétrio et al., 2000).

The benefits of turfgrass range from providing comfortable and safe place for fun and sports practicing to oxygen release due to photosynthesis process $\left(58 \mathrm{~m}^{2}\right.$ of lawn area releases per day sufficient $\mathrm{O}_{2}$ for one person). Furthermore, it decreases environment temperature, as it may reduce up to $16{ }^{\circ} \mathrm{C}$ in relation to paved surfaces. Moreover, grass may control soil pollution with a filter system formed by its roots and stolons, retaining and absorbing part of the substances that inflate in the soil (Villas Bôas and Godoy, 2006).

In Brazil, due to world important sporting events, such as World Cup in 2014 and Olympic games in 2016, demand for turfgrass increased stimulating production chain (Godoy et al., 2012), mainly Bermuda grass (Cynodon spp.) by its tolerance to water scarcity, hydric efficiency, salinity, traffic, low cuts, intense growth and fast establishment (Jiménez, 2008). Some interspecific hybrids of Cynodon dactylon $\mathrm{x}$ Cynodon transvaalensis as tifway (also known as Tifton 419), is the species most used for sporting purposes due to its high recovery power (Sartain, 2002).

However, despite all these desirable characteristics, the development of species will depend on its handling, especially about substrate in which it is installed and the intensity of luminosity.

The substrate is intended to support plants, root growth, allow gas exchange between roots and atmosphere, and supply water and nutrients (Imhoff et al., 2000; Farias et al., 2012). It is essential that chemical and physical characteristics should be observed, whereas a single component may not achieve all requirements, and it is necessary to mix two or more materials.

Among materials it is possible to mix components rich in organic matter. It may influence biological activity and its physical-chemical properties, favouring water movement and also storage. In addition, it reduces leaching nutrient losses by increasing substrate cation exchange capacity (CEC), improves structuring and increases the carbonnitrogen $(\mathrm{C} / \mathrm{N})$ ratio.

Santos et al. (2002) evaluating substrates on Zoysiagrass cv. Esmeralda development showed treatments with soil and organic matter (2:1); soil, sand and organic matter (2:1:1) and sand and organic matter (3:1) presented better results for fresh and dry matter production, showing the benefit of organic matter addition for turfgrasses. Santos et al. (2015) also verified improvement when mixed organic matter to other components for turfgrass growth instead of only subsoil and sand.
Another limiting factor is the luminance or luminosity level, which corresponds to amount of incident light on a surface. In addition to this, different species may behave in many ways; in case of tropical grass the optimum range of luminosity is between 15,000 and 16,000 lux. In Bermuda grass low incidence of light is a highly limiting factor. However, each variety has shown different levels of tolerance, being able to maintain acceptable growth and quality even with incident radiation below ideal (Coan et al. 2012).

According to Brosnan and Deputy (2008), Bermuda grass requires at least six hours of sun daily, and under solar radiation restriction, photosynthesis process may be damaged and consequently reduction on turfgrass growth. With excessive shading, Bermuda grass becomes thinner, with etiolated leaves and long internodes.

Although there is an increase interest in Bermuda grass, either for landscape or sports projects, information is missing from literature about the most favourable conditions for its full development. Thus, the objective was to evaluate the influence of different substrates combinations and luminosity levels on Bermuda grass hybrid (Cynodon dactylon x C. transvaalensis) development.

\section{Materials and Methods}

The experiment was conducted in a region whose clime was classified by Köppen as Aw type, characterized by tropical humid with rainy season in summer and dry in winter. The average annual precipitation is around $1300 \mathrm{~mm}$, distributed from October to March. The relative air humidity varies from $70 \%$ to $80 \%$ (annual average) and annual temperature mean is approximately $23.5^{\circ} \mathrm{C}$ (Binotti et al., 2014).

The cultivar Tifway 419 (interspecific hybrid of $C$. dactylon $\mathrm{x}$ C. transvaalensis) was implanted in black plastic containers $(47.5 \times 17.5 \mathrm{~cm}$ - top; $41.5 \times 11.3 \mathrm{~cm}$ - bottom; $15,5 \mathrm{~cm}$ high, $8.46 \mathrm{~L}$ volume), using donated carpets from Itograss ${ }^{\circledR}$, located in municipality of Pereira Barreto-SP.

The experimental design was factorial scheme $5 \times 4$ (substrates x shade levels) with three replicates. Plots were submitted to five substrate combination: $\mathrm{S} 1=$ soil; $\mathrm{S} 2=$ soil + sand (2:1); S3 = soil + organic matter (1:1); S4 = soil + organic matter + sand $(2: 1: 1)$ and S5 = organic matter + sand (3:1). The luminosity levels tested were: full sun, $30 \%, 50 \%$ and $80 \%$ shading. The substrates were defined according to results obtained by Santos and Castilho (2016). Structures were made of $1 / 4$ " iron rebar with $1 \times 1$ $\mathrm{x} 1 \mathrm{~m}$ (height $\mathrm{x}$ width $\mathrm{x}$ length) of dimension where black shade polypropylene shading screens were fixed.

The soil used for substrates composition is classified as Dystrophic Red Latosol, sandy loam-clay texture according to the Brazilian Soil Classification System (Embrapa, 2013). The organic matter was obtained through a composting process of vegetal residues with cattle manure. Thick sand with 0.6 to $2.0 \mathrm{~mm}$ particle size was purchased from building materials store. After substrates preparation granulometric and chemical analysis were 
performed according methodology described by Raij et al. (1987) and Embrapa (2017).

Irrigation management was daily performed, manually, receiving water until saturation to ensure field capacity of each substrate. At 57 days after planting (DAP) a reduction in grass development was verified, therefore, commercial fertilizer Forth Jardim ${ }^{\circledR}$ (N: 13\%; P: 5\%; K: 13\%; Ca: 1\%; Mg: 1\%; S: 14\%; B: 0.06\%; Cu: 0.05\%; Fe: $0.20 \%$; Mn: $0.10 \%$; Mo: $0.005 \%$; Zn: $0.20 \%$ ) was applied, following manufacturer recommendations $\left(100 \mathrm{~g} \mathrm{~m}^{-2}\right.$ and irrigating afterwards). Irrigation and fertilization were performed for did not interfere to results. The luminosity was determined daily with luximeter placed on the lawns within the structure.

At 30 (May), 150 (September) and 180 (October) days after planting (DAP) were evaluated height of aerial part - obtained by average measurement of three values using a millimetre rule. Fresh and dry mass of leaves - cutting leaves of each plot were removed using a pruning shears one centimetre from the ground and weighed on a precision scale to obtain the fresh mass. Posteriorly they were allocated into identified paper bags and dried in forced air ventilation oven at $60^{\circ} \mathrm{C}$. After stabilization the bags were weighted to obtain dry mass.

The means were submitted to Tukey test at 5\% of probability and regression analysis using SISVAR program (Ferreira, 2011).

\section{Results And Discussion}

Fertility and granulometric analysis are shown at Table 1 and 2, respectively. Substrate containing organic matter in its composition $(\mathrm{S} 3=$ soil + organic matter $(1: 1) ; \mathrm{S} 4=$ soil + organic matter + sand $(2: 1: 1)$ and S5 = organic matter + sand (3:1)) presented more macro and micronutrients increment $(\mathrm{N}, \mathrm{P}, \mathrm{K}, \mathrm{B}, \mathrm{Cu}, \mathrm{Mn}, \mathrm{Fe})$, cation exchange capacity (CEC), saturation of bases (SB), sum of bases (V) which are important factors for soil fertility.

Table 1. Fertility analysis of used substrates in the experiment.

\begin{tabular}{|c|c|c|c|c|c|c|c|c|c|}
\hline Subs. & $P$ - resin & MO & pH & $\mathbf{K}$ & $\mathrm{Ca}$ & Mg & $\mathbf{H}+\mathbf{A l}$ & Al & SB \\
\hline & $\mathrm{mg} \mathrm{dm}{ }^{-3}$ & $\mathrm{~g} \mathrm{dm}^{-3}$ & $\mathrm{CaCl}_{2}$ & \multicolumn{6}{|c|}{$\mathrm{mmol}_{\mathrm{c}} \mathrm{dm}^{-3}$} \\
\hline $\mathrm{S} 1$ & 9.0 & 20.0 & 4.4 & 1.8 & 15.0 & 9.0 & 47.0 & 4.0 & 25.8 \\
\hline $\mathrm{S} 2$ & 10.0 & 17.0 & 4.6 & 1.4 & 11.0 & 7.0 & 38.0 & 3.0 & 19.4 \\
\hline $\mathrm{S} 3$ & 892.0 & 36.0 & 5.8 & 14.4 & 177.0 & 64.0 & 26.0 & 0.0 & 255.4 \\
\hline S4 & 476.0 & 25.0 & 5.4 & 7.3 & 89.0 & 37.0 & 28.0 & 0.0 & 133.3 \\
\hline S5 & 976.0 & 36.0 & 6.3 & 9.7 & 180.0 & 65.0 & 16.0 & 0.0 & 254.7 \\
\hline I.V. & $>120.0$ & & $6.0-7.0$ & $>6.0$ & $>7.0$ & $>8.0$ & & & \\
\hline \multirow[t]{2}{*}{ Subs. } & $\mathrm{S}_{-\mathrm{SO}_{4}}$ & CEC & V & m & B & $\mathrm{Cu}$ & $\mathrm{Fe}$ & Mn & Zn \\
\hline & $\mathrm{mg} \mathrm{dm}{ }^{-3}$ & $\mathrm{mmol}_{\mathrm{c}} \mathrm{dm}^{-3}$ & \multicolumn{2}{|c|}{$\%$} & \multicolumn{5}{|c|}{$\mathrm{mg} \mathrm{dm} \mathrm{m}^{-3}$} \\
\hline $\mathrm{S} 1$ & 8.0 & 72.8 & 35.0 & 13.0 & 0.23 & 1.1 & 32.0 & 16.8 & 0.5 \\
\hline $\mathrm{S} 2$ & 5.0 & 57.4 & 34.0 & 13.0 & 0.21 & 0.9 & 34.0 & 21.5 & 0.6 \\
\hline S3 & 61.0 & 281.4 & 91.0 & 0.0 & 1.26 & 3.3 & 111.0 & 18.6 & 10.0 \\
\hline S4 & 35.0 & 161.3 & 83.0 & 0.0 & 0.75 & 2.0 & 80.0 & 16.6 & 5.1 \\
\hline S5 & 58.0 & 270.7 & 94.0 & 0.0 & 1.02 & 2.0 & 56.0 & 13.0 & 9.5 \\
\hline I.V. & $>10.0$ & & $>70.0$ & $<5.0$ & $>0.60$ & $>0.8$ & $>12.0$ & $>5.0$ & $>1.2$ \\
\hline
\end{tabular}

I.V. = ideal values; $\mathrm{S} 1=$ soil; $\mathrm{S} 2=$ soil + sand $(2: 1) ; \mathrm{S} 3=$ soil + organic matter $(1: 1) ; \mathrm{S} 4=$ soil + organic matter + sand $(2: 1: 1)$ e $\mathrm{S} 5=$ organic matter + sand $(3: 1)$.

The $\mathrm{pH}$ value also increased compared to substrate $\mathrm{S} 1$ containing only soil. In this case, this substrate had low $\mathrm{pH}$ characterized as acid. It was possible to notice organic matter was able to increase $\mathrm{pH}$ value. Nevertheless, only S5 is within the acceptable range of acidity. On the other hand, decreased unfavourable elements for plant development such as exchangeable aluminium $(\mathrm{Al})$, potential acidity $(\mathrm{H}$ $+\mathrm{Al}$ ) and aluminum saturation (m). 
Table 2. Granulometric analysis of used substrates in the experiment.

\begin{tabular}{|c|c|c|c|c|}
\hline Substrate & Clay & Silt & Sand & Texture \\
\hline S1 & 32,8 & 7,9 & 59,3 & Medium \\
\hline S2 & 21,6 & 4,0 & 74,4 & Medium \\
\hline S3 & 22,3 & 16,9 & 60,8 & Medium \\
\hline S4 & 20,7 & 6,0 & 73,3 & Medium \\
\hline S5 & 12,3 & 4,1 & 83,5 & Sandy \\
\hline
\end{tabular}

$\mathrm{S} 1=$ soil $; \mathrm{S} 2=\operatorname{soil}+\operatorname{sand}(2: 1) ; \mathrm{S} 3=$ soil + organic matter $(1: 1) ; \mathrm{S} 4=$ soil + organic matter + sand $(2: 1: 1)$ e $\mathrm{S} 5=$ organic matter + sand $(3: 1)$.

According to Jiménez (2008), the satisfactory $\mathrm{pH}$ value for Bermuda grass is between 5.5 and 7.5, with ideal range varying from 6 to 7, therefore, the substrate S3 presents a satisfactory $\mathrm{pH}$ and $\mathrm{S} 5$ presents an ideal $\mathrm{pH}$.

Godoy et al. (2012) characterized Bermuda grass hybrid as being a species with high nutritional requirement. Based on this, it is possible to consider that substrates $\mathrm{S} 1$ and $\mathrm{S} 2$ contained low $\mathrm{P}$ and $\mathrm{K}$ contents, while other substrates presented high content of the same nutrients (Table 1).

According to Santos et al. (2008), phosphorus values are inversely proportional to clay content. Based on Tables 1 and 2 and as presented by Bastos and Carvalho (2002), substrates S1 and S2 presented very low levels of phosphorus (below $26 \mathrm{mg} \mathrm{dm}^{-3}$ ), while S3 and S4 were considered better with values above $120 \mathrm{mg} \mathrm{dm}^{-3}$ and above $180 \mathrm{mg} \mathrm{dm}^{-3}$ for the substrate S5.

The substrates granulometric analysis (Table 2) classified $\mathrm{S} 1$ to $\mathrm{S} 4$ as medium texture with clay ranging from $20.7 \%$ to $32.8 \%$ and sand from $73.3 \%$ to $59.3 \%$. On the other hand, S5 was classified as sandy texture with $12.3 \%$ clay and $83.5 \%$ sand.
The textural class is an important characteristic as its variation is practically null over time and the use and management do not influence, furthermore, it is determined by the substrate components distribution of particles according to their size. In this way, it is a primordial factor when choosing the species to be cultivated in the area. This characteristic, with clay type, affects other physical properties, such as drainage and water retention, aeration and substrates consistency (Reinert et al., 2008).

Luminosity is an important factor for grasses development belonged to group $\mathrm{C} 4$. One of the inherent characteristics of this group is they continue to increase their photosynthetic rate up 60,000 lux light intensity (Oliveira et al., 1973).

According to Morocho (2009), the optimum range of luminosity for tropical grasses is between 15,000 and 16,000 lux. Thus, according to Figure 1, at full sun all months showed luminosity above the ideal, except in September. At $30 \%$ of shading, luminous intensity was reached in April, May, July, August and October. On the other hand, $50 \%$ and $80 \%$ of shading did not reach sufficient luminosity for good development.

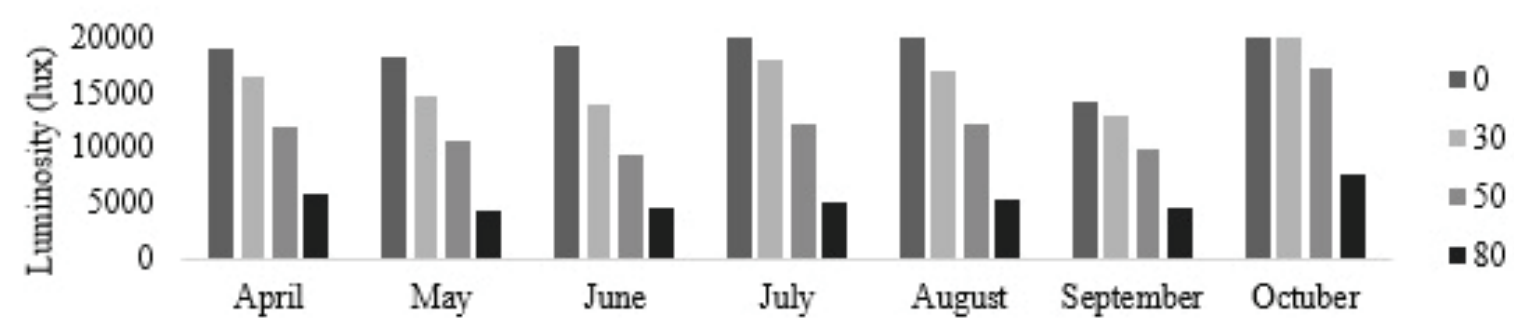

Figure 1. Average luminosity (lux) at each level of shading during experimental period.

According to regression analysis, it was found significant data for all evaluated period. Figure 2A and 2B shows regression analysis of height at 30 and 150 DAP, respectively. It was possible to verify quadratic behaviour with a tendency for the highest etiolation in treatments with increasing shading intensity. With regression equation derivation maximum shading point was $83.75 \%$ (30 DAP) and the minimum point was $12.31 \%$ (150 DAP). At 180 DAP (Figure 2C), we also observed quadratic tendencies in regression curve with increasing height as luminosity decreased. By deriving the equation, the maximum height was obtained when shading was $74.2 \%$. 

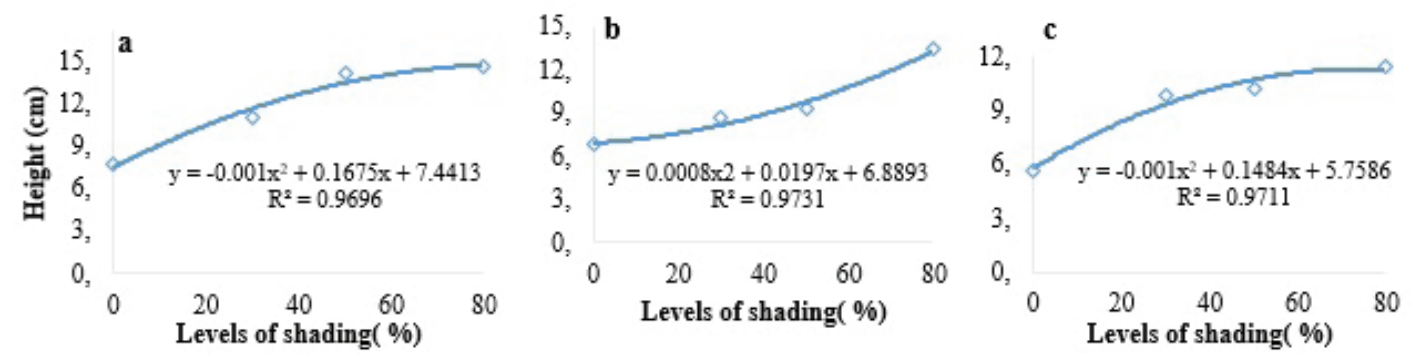

Figure 2. Regression analysis of Bermuda grass height (cm) at 30 (A), 150 (B) and 180 (C) days after planting at different levels of shading. Significant regression at $5 \%$ of probability.

The presented results differed from found by Veras et al. (2010) evaluating the influence of shading on Andropogon gaynus development. The authors verified there was no significant difference between brightness levels of 62.5 ; $74.0 ; 82.4 \%$ and full sun, in which they obtained 551.5; $653.5 ; 730.5$ and 882.7 lux, respectively.

Schreiner (1987) studying the effect of $0,25,50$ and $80 \%$ shading levels in four different grasses (Brachiaria decumbens, Digitaria decumbens, Hemalthria altissima and Paspalum notatum), obtained smaller heights when grasses were submitted to more intense shading, divergent from observed in the present study.

On the other hand, Maciel et al. (2011) studying the influence of $50 \%$ of shade and full sun on Bermuda grass growth, presented results similar to those found in the present study, in which the grass presented higher heights when cultivated as shade. To explain these results, Martins et al. (2009) argued the exposure to less light intensity requires the plant to be more efficient at photosynthesis structure, stimulating greater plant growth. Differently from what objectified for forage grasses, gain in height is not interesting for grasses used in landscaping and sports lawns, because it increases necessity of cuts enhancing maintenance costs.

Analysing each shading level within substrates, at 30 DAP (Table 3), it is possible to observe in full sun substrates S3 and S5 presented higher fresh mass, whereas substrates $\mathrm{S} 1$ and S2 produced smaller masses. At 30\% shading, substrates S1 and S4 did not differ statistically among themselves, producing the largest masses, but they differed from others substrates that after cutting obtained the smallest green masses. With half of luminosity $(50 \%)$ substrates containing organic matter in their composition (S3, S4 and S5) were the ones that developed more presenting larger masses, consequently, differed statistically from substrates $\mathrm{S} 1$ and S2. The greatest decrease of the luminosity $(80 \%$ of shading) made substrates S1 and S3 highlighted in fresh mass production. Although they did not differentiate between them, both substrates were statistically larger than other. 
Table 3. Bermuda grass (C. dactylon $\mathrm{x}$ C. transvaalensis) fresh mass $\left(\mathrm{g} \mathrm{m}^{-2}\right)$ mean submitted to different shade treatments and substrates at 30, 150 and 180 days after planting (DAP).

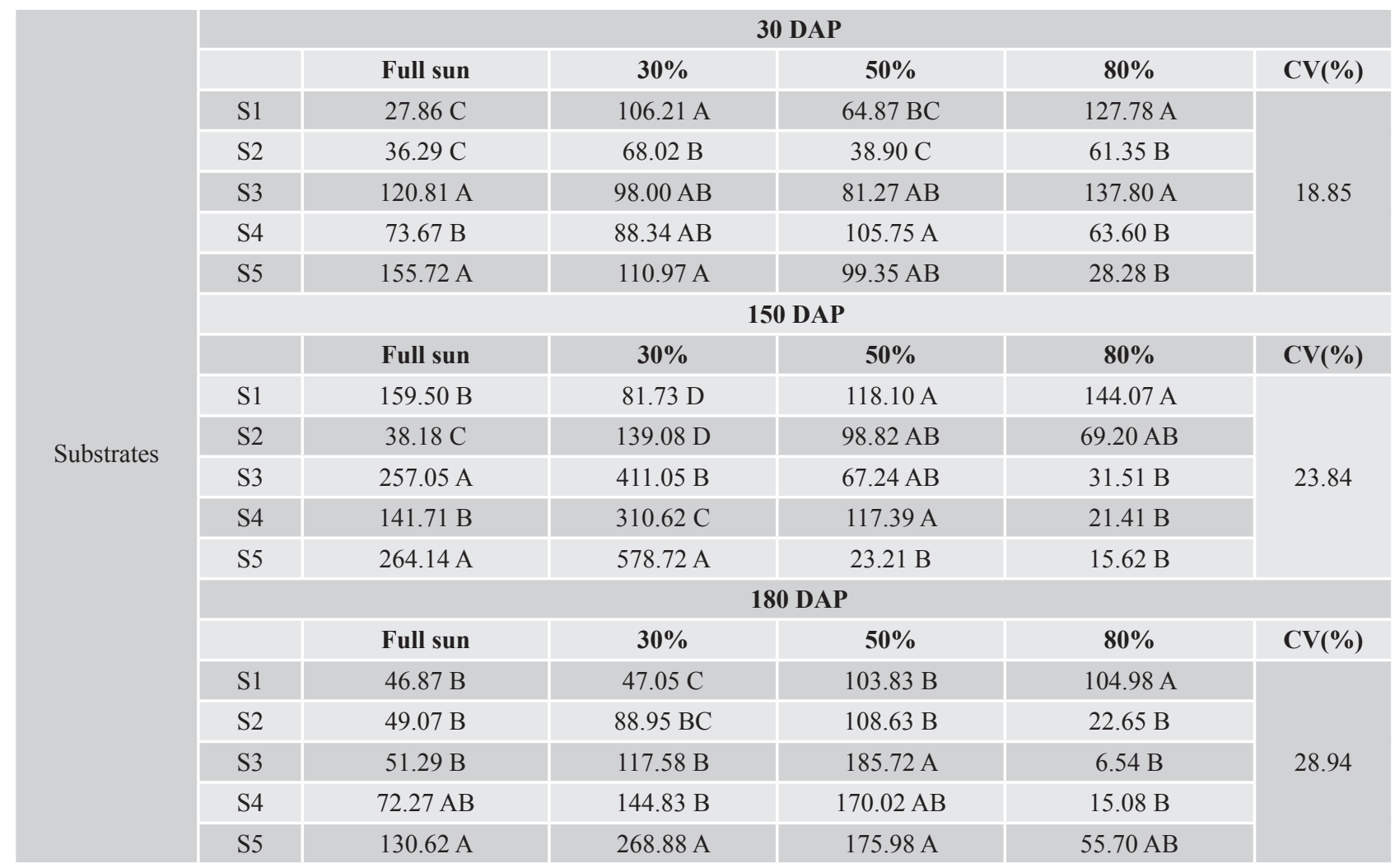

The means followed by same capital letter in column do not differ statistically from each other at $5 \%$ probability level for Tukey test. S1 $=$ soil; S2 $=$ soil + sand $(2: 1) ; \mathrm{S} 3=$ soil + organic matter $(1: 1) ; \mathrm{S} 4=$ soil + organic matter + sand $(2: 1: 1)$ e S5 $=$ organic matter + sand $(3: 1)$.

At five months of evaluation (150 DAP), when analysing the extremes, full sun and $80 \%$ shading, substrates S3, S4 and S5 produced discrepant fresh masses between eight and seventeen times in full sun in detriment of the lowest shading (Table 3 ). The presence of organic matter in these substrates may have provided greater availability of nutrients (Table 1)

For $30 \%$ shading substrate S5 appeared again with the highest value of fresh mass, the lowest value occurs in the substrates S1 and S2, and may be caused by the nutritional composition of these substrates that present lower contents in relation to S5 (Table 1). For 50\% shading substrates S1 and S4 presented the highest values and substrate S5 the lowest value.

At six months after planting (180 DAT), in full sun, substrate S5 presented greater fresh mass accumulation, not differing from substrate S4, however, it was differentiated from others by almost three times more. One possible explanation is the presence of organic matter has increased the nutrients availability; favouring fresh mass accumulation (Table 1) and presence of sand may have favoured drainage (Table 2).

At 30\% shading, the largest green mass was observed for S5 that differentiated statistically from all other substrates.
With half of luminosity (50\%) substrates containing organic matter in their composition presented the largest green masses after cutting, and S3 and S5 differed statistically from S1 and S2. Reducing the brightness to $80 \%$ shading showed S1 presented higher fresh mass in relation to all other substrates, this reduction was quite significant ranging from two to sixteen times less. The reduction below 5,000 lux (Figure 1) associated with lower clay content may have impaired performance of substrates S2 to S4.

The Figure 3A, with regression curves of first fresh mass evaluation (30 DAP), shows linear behaviour for S1, S2, S5 and quadratic curves for the others. By deriving the equations, it was possible to determine that the minimum point of fresh mass accumulation in the substrate S3 was verified $37.21 \%$ shading, while maximum point for S4 was $38.30 \%$ shading. Both S1 and S2 presented increase in fresh mass accumulation as shading level increased. In contrast, the substrate S5 showed an inverse behaviour.

The regression curves for second evaluation data, at 150 DAP (Figure 3B), all substrates presented quadratic behaviour. It was possible to verify shading level with the lowest value was $41.05 \%$ for substrate $\mathrm{S} 1$ and maximum shading point ranged from $11.03 \%(\mathrm{~S} 3)$ to $42.84 \%(\mathrm{~S} 2)$, with mean of $23.77 \%$. 


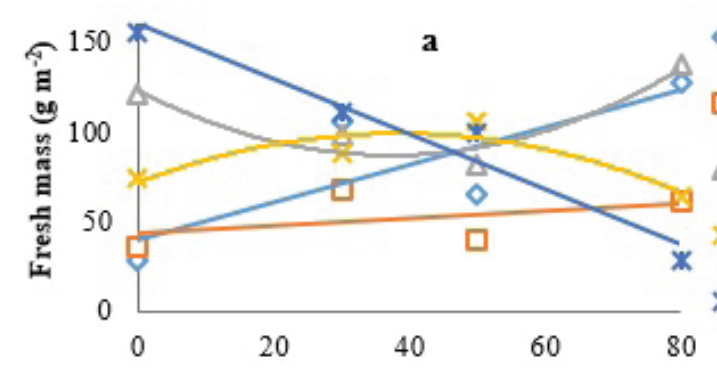

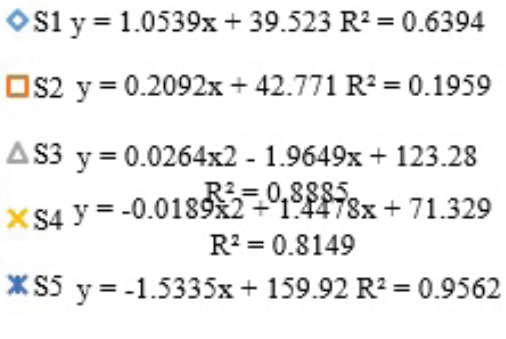

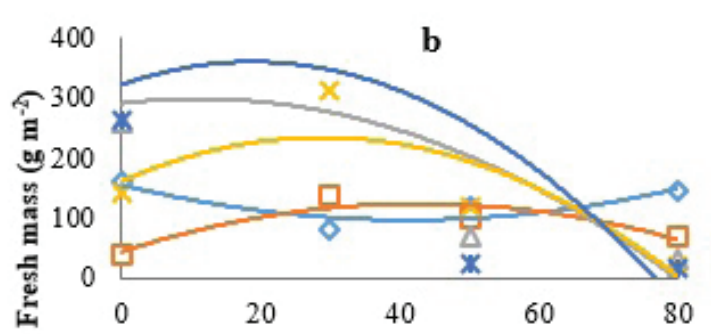

$\diamond \mathrm{S} 1 \mathrm{y}=0.0346 \mathrm{x}^{2}-2.8409 \mathrm{x}+154.77 \mathrm{R}^{2}=$

$\square \mathrm{S} 2 \mathrm{y}=-0.0435 \mathrm{x}^{2}+3.7896 \mathrm{x}+43.828 \mathrm{R}^{2}=$

$\mathrm{y}=-0.0632 \mathrm{x}^{2}+1.30457 \mathrm{x}+290.86$

$\triangle \mathrm{S} 3 \quad \mathrm{R}^{2}=0.5844$

$\times$ S4 $y=-0.0883 x^{2}+5.0798 x+160.91$

$\mathrm{XS}^{2}=0.7116$

$x_{\text {S5 }} y=-0,1074 x^{2}+4,0337 x+322,18$

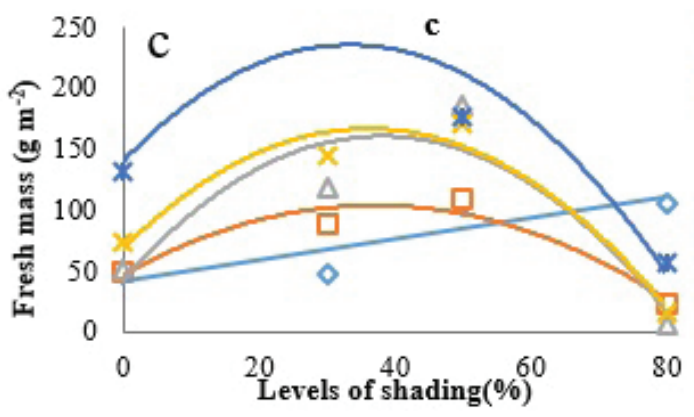

$\diamond \mathrm{S} 1 \mathrm{y}=0.8506 \mathrm{x}+41.659 \mathrm{R}^{2}=0.7454$

$\square \mathrm{S} 2 \mathrm{y}=-0,042 \mathrm{x}^{2}+3,1034 \mathrm{x}+45,977$

$\Delta \mathrm{S} 3 \mathrm{y}=-0,0818 \mathrm{x}^{2}+6,2199 \mathrm{x}+41,957$

$\mathrm{R}^{2}=0,8389$

$\times S_{4} y=-0,0758 x^{2}+5,468 x+67,622$

$\mathrm{R}^{2}=0,9507$

X S5 $y=-0,0862 x^{2}+5,7399 x+139,35$

$\mathrm{R}^{2}=0,8914$

Figure 3. Bermuda grass (C. dactylon $\mathrm{x}$ C. transvaalensis) fresh mass $\left(\mathrm{g} \mathrm{m}^{-2}\right.$ ) regression analysis at (A) 30 and (B) 150 days after planting at different levels of shading. $\mathrm{S} 1=$ soil; $\mathrm{S} 2=\operatorname{soil}+\operatorname{sand}(2: 1) ; \mathrm{S} 3=\operatorname{soil}+$ organic matter $(1: 1)$; $\mathrm{S} 4=$ soil + organic matter + sand $(2: 1: 1)$ e $\mathrm{S} 5=$ organic matter + sand (3:1). Significant regression at $5 \%$ of probability

Comparing fresh mass with height at 150 DAP, verified there was an increase in height as the light decreased, however the fresh mass presented opposite behaviour, reducing its value as the level of shading increased (Figures $2 \mathrm{~B}$ and $3 \mathrm{~B})$.

Figure 4 shows linear behaviour for $\mathrm{S} 1$ and quadratic for S2, S3, S4 and S5 regression equations, shows a maximum point varying from 33.29 to $38.02 \%$ shading (respectively the substrates S5 and S3).

Only S1 showed tendency similar to height at 180 days, with an increase in its value as shading increases, on other substrates the fresh mass did not follow the same trend as the Bermuda grass height (Figures 2C and 4). 

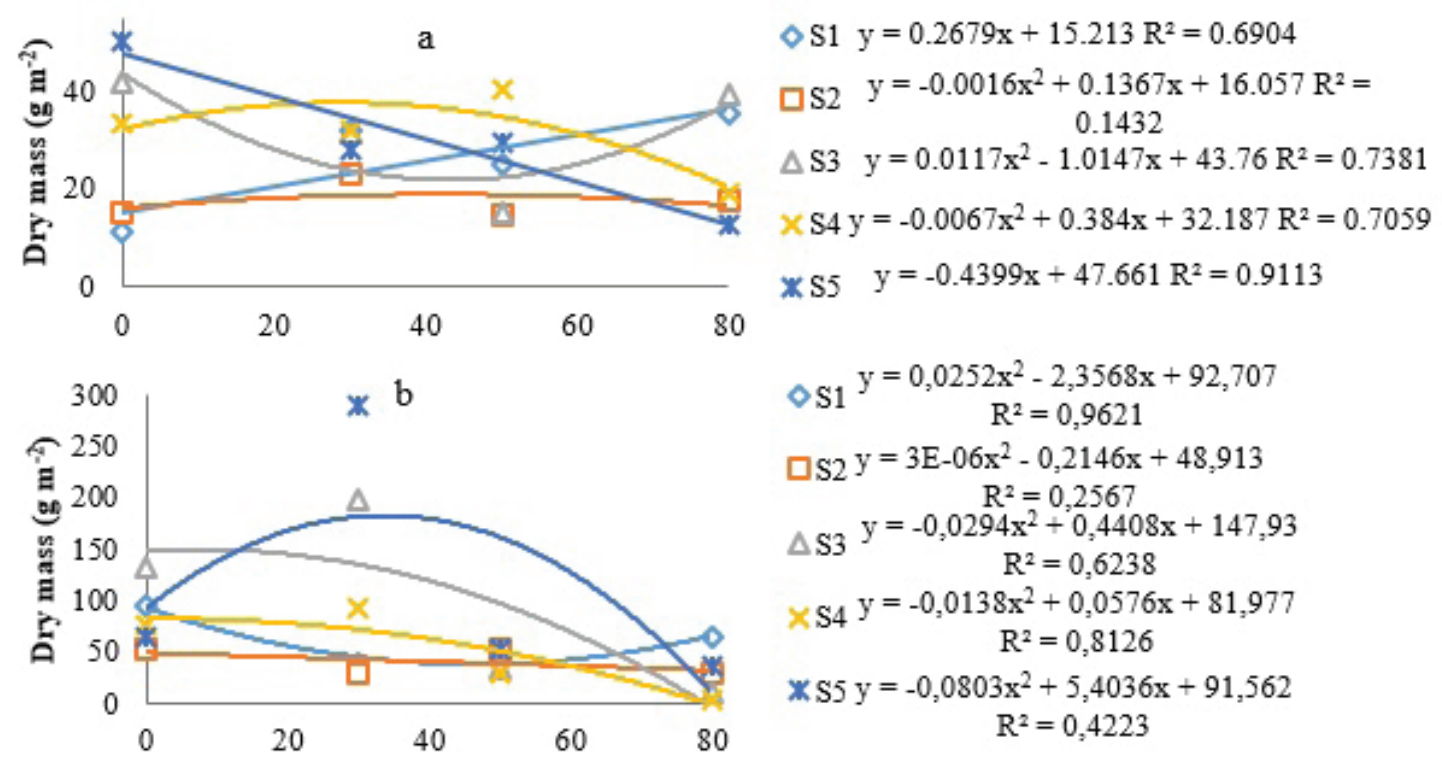

$\Delta_{\mathrm{S}} \mathrm{y}=0,0252 \mathrm{x}^{2}-2,3568 \mathrm{x}+92,707$
$\mathrm{R}^{2}=0,9621$

$\square \mathrm{S} 2 \mathrm{y}=3 \mathrm{E}-06 \mathrm{x}^{2}-0,2146 \mathrm{x}+48,913$

$\mathrm{R}^{2}=0,2567$

$\Delta S_{3} y=-0,0294 x^{2}+0,4408 x+147,93$

$\times \mathrm{S}_{4} \mathrm{y}=-0,0138 \mathrm{x}^{2}+0,0576 \mathrm{x}+81,977$

X S5 y $=-0,0803 \mathrm{x}^{2}+5,4036 \mathrm{x}+91,562$

$\mathrm{R}^{2}=0,4223$

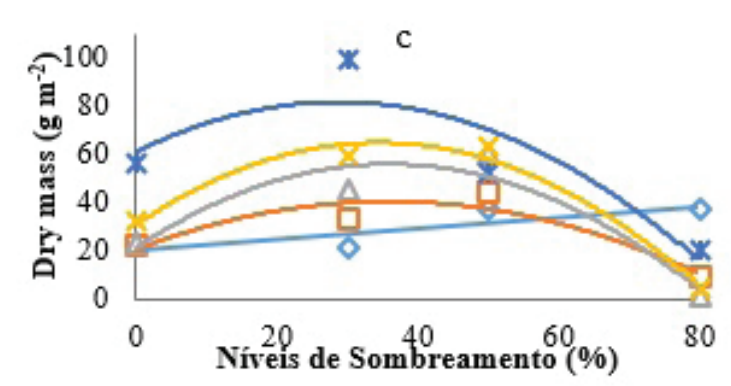

$$
\begin{aligned}
& \text { ○ } 1 \mathrm{y}=0.2176 \mathrm{x}+20.489 \mathrm{R}^{2}=0.6972 \\
& \square \mathrm{S} 2 \mathrm{y}=-0.0155 \mathrm{x}^{2}+1.1098 \mathrm{x}+20.417 \\
& \begin{array}{c}
R^{2}=0.8649 \\
\Delta S 3 y=-0,0268 x^{2}+1,9296 x+21,18
\end{array} \\
& \begin{array}{c}
R^{2}=0,901 \\
X S 4 y=-0,0285 x^{2}+1,9717 x+30,68
\end{array} \\
& R^{2}=0,9782 \\
& \text { ЖS5 } y=-0,025 x^{2}+1,4358 x+60,951 \\
& \mathrm{R}^{2}=0,7883
\end{aligned}
$$

Figure 4. Bermuda grass (C. dactylon $\mathrm{x}$ C. transvaalensis) fresh mass $\left(\mathrm{g} \mathrm{m}^{-2}\right)$ regression analysis at 180 days after planting at different levels of shading. S1 = soil; S2 = soil + sand (2:1); S3 = soil + organic matter $(1: 1) ; \mathrm{S} 4=$ soil + organic matter + sand $(2: 1: 1)$ e $S 5=$ organic matter + sand $(3: 1)$. Significant regression at $5 \%$ of probability.

Organic matter has the characteristic of raising soil moisture retention capacity by absorbing a large amount of water - from four to six times its own weight (Mello et al, 2005). In addition, Maciel et al. (2010) reported Bermuda grass does not perform well in areas with poor drainage, therefore, may be one of the reasons for lower fresh mass accumulation at S5 substrate due to its higher organic matter content (Table 1). According to Castro et al. (2009), plants submitted to less light intensity levels have more compact leaves with reduced volume, influencing directly fresh mass value.

Oliveira et al. (2013) evaluating behaviour of Andropogon gayanus and Panicum maximum under shading found at $50 \%$ of shading fresh mass accumulation was lower than the $30 \%$, as verified at present study (Figure 3). Comparing the presence or absence of shading it was possible to observe for these species that shading favoured fresh mass accumulation, being different from substrates $\mathrm{S} 1, \mathrm{~S} 2$ and S3 and similar to observed at substrates S4 and S5 of present work (Figure 3).
According to Castro et al. (2009), the greatest accumulation of fresh mass in full sun is due to leaf thickness increase. This is a result of greater number of layers of paliadic cells. In this case, in shaded leaves reduction in thickness occurs due to reduction in layers of parenchymatic tissues, showing shading damages fresh mass gain, as observed at present study.

Perini et al. (2011), evaluating the effect of shading on Cymbopogon nardus development observed in shading condition a lower gain of fresh mass, but higher development in height, corroborating with the present work.

In relation to dry mass, comparing substrates within each shading level, at first evaluation (30 DAP), it can be observed in full sun substrates $\mathrm{S} 1$ and $\mathrm{S} 2$ presented lower dry mass (Table 4), this may be caused by lower nutrients availability, due to lower amount of organic matter presented (Table 1). At $50 \%$ of shade, substrate S4 presented higher mass, however, did not differ statistically from S1 and S5. The lower accumulation was observed in $\mathrm{S} 2$ and $\mathrm{S} 3$, which also did not differ from S1 and S5. 
At level $80 \%$, substrate S3 presented the highest dry mass mean, not statistically different from $\mathrm{S} 1$, whereas the lowest gain was observed in S2 and S5, which did not differ from S4 (Table 4). The reduction of dry mass at S4 and S5 may have been influenced by organic matter presence (Table 1), which as previously explained may affect substrate drainage, compromising grass development.

At 150 DAP (Table 4), only full sun and $30 \%$ of shading presented statistical differences. Ant first S1, S3, S4 and
S5 did not differ within each other, however, differed from $\mathrm{S} 2$. At second, S5 presented the highest dry mass values differing from all of others.

At third evaluation of dry mass (180 DAP), in which it is possible to verify in S3 and S4 there was development influence according to shading. At S3, intermediate levels of shading (30\% and 50\%) presented the highest dry mass indices, not statistically different from each other. At $80 \%$ of shading had the worst performance for substrates S2 to S4.

Table 4. Bermuda grass (C. dactylon x C. transvaalensis) dry mass $\left(\mathrm{g} \mathrm{m}^{-2}\right)$ mean submitted to different shade treatments and substrates at 30,150 and 180 days after planting (DAP).

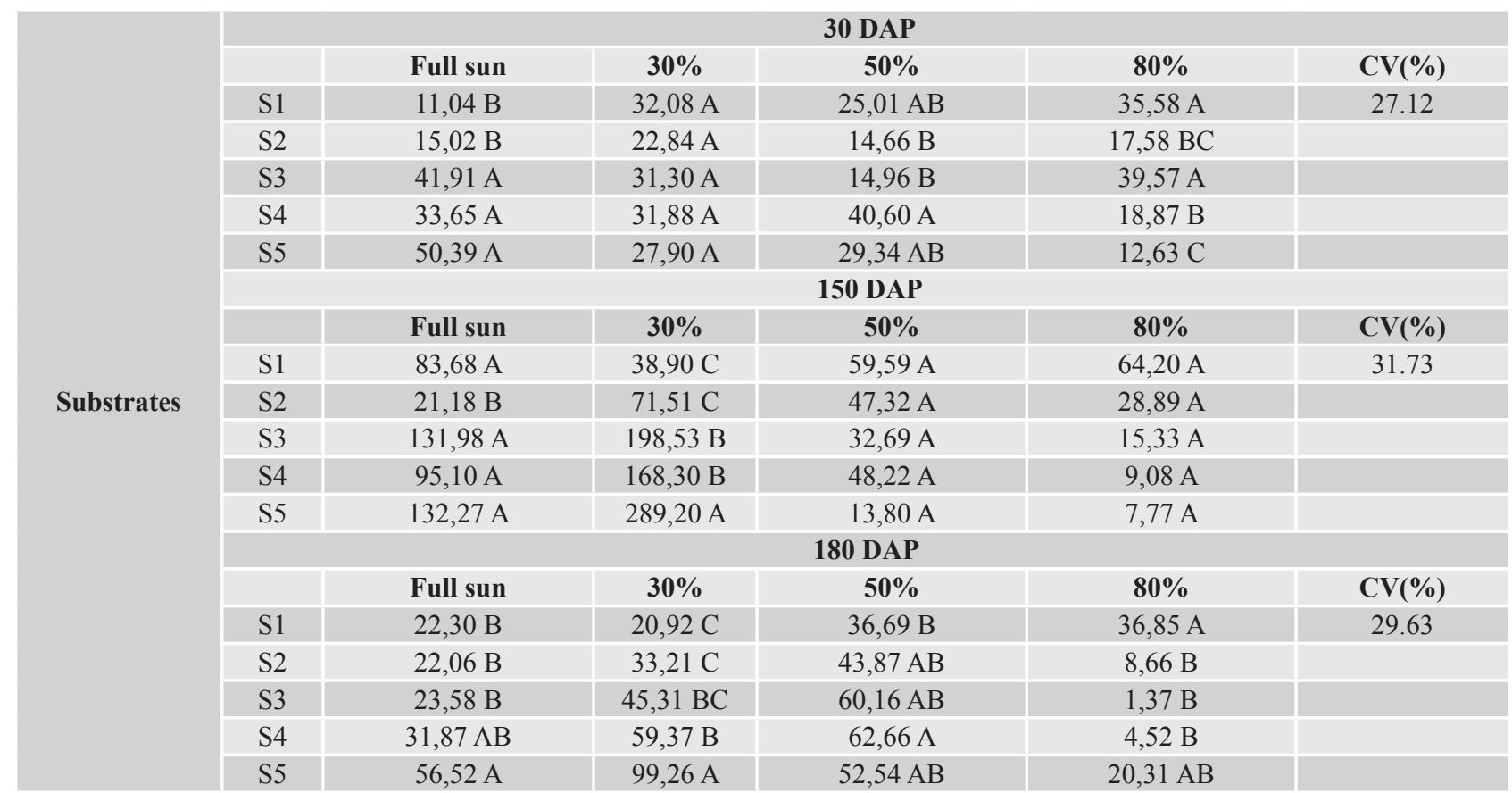

The means followed by same capital letter in column do not differ statistically from each other at $5 \%$ probability level for Tukey test. S1 = soil; S2 = soil + sand $(2: 1) ; \mathrm{S} 3=$ soil + organic matter $(1: 1) ; \mathrm{S} 4=$ soil + organic matter + sand $(2: 1: 1)$ e S5 $=$ organic matter + sand $(3: 1)$.

The regression curves of dry mass at 30 days (Figure 5A) showed linear behaviour to $\mathrm{S} 1$ and S5, but with opposite tendencies, while S1 presented increase in dry mass as shading levels increase. In relation to S5 there was reduction. Substrates S2, S3 and S4 present a quadratic behaviour, deriving curves equations, it is observed the maximum shading point for dry mass gain varied between $28,66 \%$ and $42,72 \%$, respectively, for substrates S4 and S2 and minimum shading point was observed in substrate S3 (43.36\%). At 30 days, dry mass curve tendency was similar to fresh mass curve (Figures 3 and $5 \mathrm{~A})$.
At Figure 5B, 150 DAP, substrates presented quadratic behaviour with low dry mass accumulation for more intense levels of shading. The maximum point varied between 6.74 and $40.46 \%$ of shading, for substrates S3 and S2, respectively, having a mean value of $20.43 \%$; S1 obtained the minimum value at $45.01 \%$ of shading. At this evaluation, it may be observed dry mass (Figure 7) presented similar behaviour to observed at fresh mass (Figure 4). However, when compared to height (Figure 2B), distinctions may be observed, as there was no difference among substrates for height, with level of shading increase, there was also an increase in height. For dry mass this behaviour was inverse. 

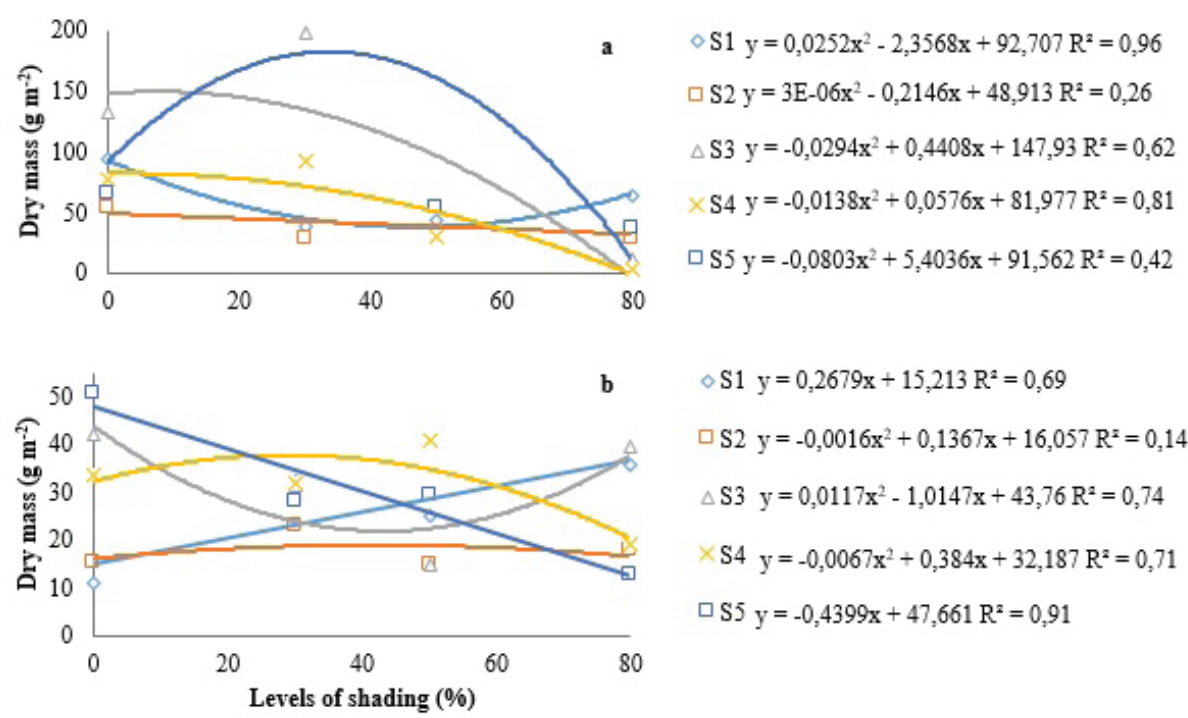

$$
\begin{aligned}
& \triangle S 1 y=0,2679 x+15,213 R^{2}=0,69 \\
& \square S 2 y=-0,0016 x^{2}+0,1367 x+16,057 R^{2}=0,14 \\
& \triangle S 3 y=0,0117 x^{2}-1,0147 x+43,76 R^{2}=0,74 \\
& \triangle S 4 y=-0,0067 x^{2}+0,384 x+32,187 R^{2}=0,71 \\
& \square S 5 y=-0,4399 x+47,661 R^{2}=0,91
\end{aligned}
$$

Figure 5. Bermuda grass (C. dactylon $\mathrm{x}$ C. transvaalensis) dry mass $\left(\mathrm{g} \mathrm{m}^{-2}\right)$ regression analysis at (A) 30 days and (B) 150 after planting at different levels of shading. $\mathrm{S} 1=$ soil; $\mathrm{S} 2=$ soil + sand $(2: 1)$; S3 = soil + organic matter (1:1); $\mathrm{S} 4=$ soil + organic matter + sand (2:1:1) e S5 = organic matter + sand (3:1). Significant regression at $5 \%$ of probability.

The regression curve of the dry mass at 180 DAP was presented in Figure 8, and it may be observed quadratic behaviour, in which the maximum point of dry mass is verified at $34.87 \%$ of shading level.

Comparing dry mass to the fresh mass at 180 DAP
(Figure 6) it is possible to verify similar behaviour between variables, with maximum shading points close to them (Figure 5). Analyzing the height (Figure 2C), it was observed there was increase for height according to shading increment.
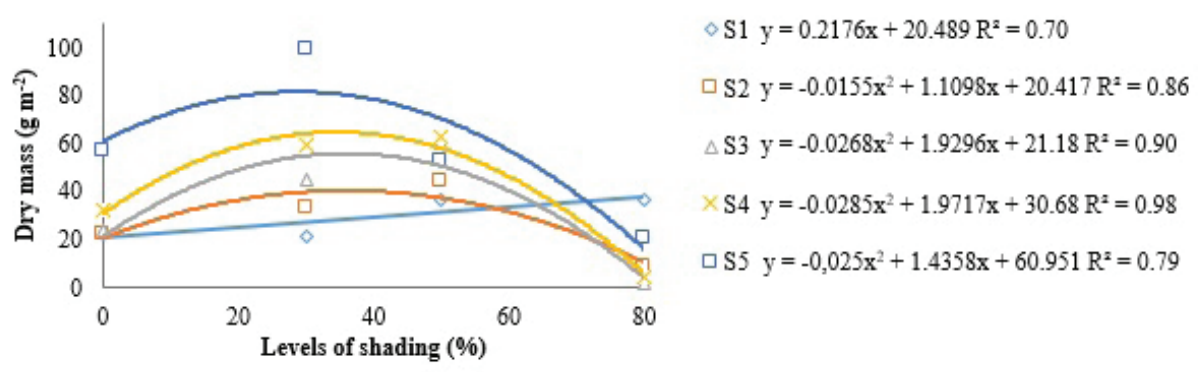

Figure 6. Bermuda grass (C. dactylon x C. transvaalensis) dry mass $\left(\mathrm{g} \mathrm{m}^{-2}\right)$ regression analysis 180 days after planting at different levels of shading. S1 = soil; S2 = soil + sand $(2: 1) ; \mathrm{S} 3=$ soil + organic matter $(1: 1) ; \mathrm{S} 4=$ soil + organic matter + sand $(2: 1: 1)$ e S5 $=$ organic matter + sand $(3: 1)$. Significant regression at $5 \%$ of probability.

Ferreira et al. (2010) evaluating Panicum maximum cv. Tanzania development under shading conditions, verified at 60 days the greatest accumulation of dry mass in conditions of greater luminosity, differing from the present result.

In addition to it, Durr and Rangel (2000) studying the influence of shading and soils on Panicum maximum development discovered higher dry mass in the most intense shading and soil containing greater amount of organic matter.

Salles et al. (2014) evaluating the effect of shading due to spacing between trees in silvopastoral system with Urochoa brizantha cv. Xaraés, verified with increase in spacing and consequent reduction in shading, there was an increase in dry mass for grass. 


\section{Conclusions}

Shading interfered at Bermuda grass performance tolerating intermediate shading (30\% and 50\%).

Although higher availability of nutrients in substrates containing organic matter, it has affected grass development, especially when it was submitted to the most intense levels of shading.

\section{Author Contribution}

J.A.A. ${ }^{0000-0002-3224-8524}$ : field analysis, data collection and analysis, manuscript preparation and review. M.K.P. ${ }^{0000-0001-748-6327}$ : manuscript critical review, translation. K.I.H. ${ }^{0000-0002-2097-5302}$ :

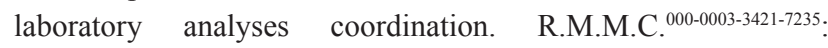
manuscript preparation and review, approval of manuscript final version.

\section{Acknowledgments}

Authors acknowledge Coordination of Superior Level Staff Improvement (CAPES) for financial support and Itograss ${ }^{\circledR}$ for grass donation.

\section{References}

BASTOS, A.R.R.; CARVALHO, J.G. Manejo do solo e adubação para plantas ornamentais. Lavras: UFLA, 2002. 147 p.

BINOTTI, F.F.S.; ARF, O.; CARDOSO, E.D.; SÁ, M.E.; BUZETTI, S. Manejo do nitrogênio em cobertura do feijoeiro de inverno no sistema plantio direto. Revista de Agricultura Neotropical, v.1, n.1, p.58-64, 2014. DOI: https://doi.org/10.32404/rean.v1i1.226

BROSNAN, J.T.; DEPUTY, J. Bermudagrass: turf management. [S. 1.: s. n.], 2008. Disponível em: <http:// turfgrass.ctahr.hawaii.edu/downloads/Bermudagrass NEW2.pdf $>$. Acesso em: 16 fev. 2013.

CASTRO, E.M.; PEREIRA, F.J.; PAIVA. R. Histologia vegetal: estrutura e função de órgãos vegetativos. Lavras: UFLA, 2009. $234 \mathrm{p}$.

COAN, R.M.; TURCO, J.E.P.; PIVETTA, K.L.F.; COSTA, M.N.; MATEUS, C.M.D. Emerald zoyzia grass development regarding photosynthetically Active radiation in different slopes. Engenharia Agrícola, v.32, n.3, p.201509, 2012. DOI: $10.1590 /$ S0100-69162012000300009

DEMÉTRIO, V.A.; CHADDAD, J.; LIMA, A.M.L.P.; CHADDAD JÚNIOR, J. Composição paisagística em parques e jardins. Piracicaba: FEALQ, 2000. v.8. 103p.
DURR, P.A.; RANGEL, J. The response of Panicum maximum to a simulated subcanopy environment. I. Soil $\mathrm{x}$ shade interaction. Tropical Grasslands, v.34, p.110-117, 2000

EMBRAPA - Empresa Brasileira de Pesquisa Agropecuária. Manual de métodos de análise de solo. 3ed. Rio de Janeiro, 2017. 212p.

EMBRAPA - Empresa Brasileira de Pesquisa Agropecuária. Sistema brasileiro de classificação de solos. Rio de Janeiro, 2013. 353p.

FARIAS, W.C.; OLIVEIRA, L.L.P.; OLIVEIRA, T.A.; DANTAS, L.L.G.R.; SILVA, T.A.G. Caracterização física de substratos alternativos para produção de mudas. Agropecuária Científica no Semi-Árido, v.8, p.01-06, 2012. DOI: http://dx.doi.org/10.30969/acsa.v8i3.187

FERREIRA, D.F. Sisvar: a computer statistical analysis system. Ciência e Agrotecnologia, v.35, n.6, p.1039-1042, 2011. DOI: dx.doi.org/10.1590/S141370542011000600001

FERREIRA, D.J.; ZANINE, A.M.; SOUTO, S.M.; DIAS, P.F. Capim tanzânia (Panicum maximum) sob sombreamento e manejo de corte. Archivos de Zootecnia, v. 59, n.225, 2010.

GODOY, L.J.G.; VILLAS BÔAS, R.L.; BACKES, C. Produção de tapetes de grama Santo Agostinho submetida a doses de nitrogênio. Semina: Ciências Agrárias, v.33, n.5, p.1703-1716, 2012. DOI: 10.5433/1679-0359.2012v3 $3 \mathrm{n} 5 \mathrm{p} 1703$

IMHOFF, S.; SILVA, A.P.; TORMENA, C.A. Aplicações da curva de resistência no controle da qualidade física de um solo sob pastagem. Pesquisa Agropecuária Brasileira, v.35, p.1493-1500, 2000.

JIMÉNEZ, R.J.M. Céspedes ornamentales y deportivos. [S. 1.]: Junta de Andalucía, 2008. 527 p.

MACIEL, C.D.G.; POLETINE, J.P.; RAIMONDI, M.A.; RODRIGUES, M.; RIBEIRO, R.B.; COSTA, R.S.; MAIO, R.M.D. Desenvolvimento de gramados submetidos à aplicação de retardadores de crescimento em diferentes condições de luminosidade. Planta Daninha, v.29, n.2, p.383-395, 2011. DOI: dx.doi.org/10.1590/S010083582011000200016 .

MACIEL, C.D.G.; SOUZA, J.I.; HAMA, J.T. Levantamento fitossociológico de plantas daninhas em jardins residenciais com grama esmeralda em Ourinhos - SP. Global Science and Technology, v.3, n.2, p.39-48, 2010. 
MARTINS, J.R.; ALVARENGA, A.A.; CASTRO, E.M.; SILVA, A.P.O.; OLIVEIRA, C.; ALVES, E. Anatomia foliar de plantas de alfavaca-cravo cultivadas sob malhas coloridas. Ciência Rural, v.39, n.1, p.82-87, 2009. DOI: dx.doi.org/10.1590/S0103-84782008005000040.

OLIVEIRA, B.A.D.; FARIA, P.R.S.; SOUTO, S.M.; CARNEIRO, A.M.; DÖBEREINER, J.; ARONOVICH, S. Identificação de gramíneas tropicais com via fotossintética "C4" pela anatomia foliar. Pesquisa Agropecuária Brasileira, v.8, p.267-271, 1973.

OLIVEIRA, F.L.R.; MOTA, V.A.; RAMOS, M.S.; SANTOS, L.D.T.; OLIVEIRA, N.J.F.; GERASEEV, L.C. Comportamento de Andropogon gayanus cv. 'Planaltina' e Panicum maximum cv. 'Tanzânia' sob sombreamento. Ciência Rural, v.43, n.2, p.348-354, 2013. DOI: dx.doi. org/10.1590/S0103-84782013000200026.

PERINI,V.B.M.; CASTRO, H.G.; CARDOSO, D.P.; LIMA, S.O.; AGUIAR, R.W.S; MOMENTÉ, V.G. Efeito da adubação e da luz na produção de biomassa do capim citronela. Bioscience Journal, v.27, n.6, p.924-931, 2011.

RAIJ, B.V; QUAGGIO, J.A.; CANTARELLA, H.; FERREIRA, M.E.; LOPES, A.S.; BATAGLIA, O.C. Análise química do solo para fins de fertilidade. Campinas, Fundação Cargill, 1987. 170p.

REINERT, D.J.; ALBUQUERQUE, J.A.; REICHERT, J.M.; AITA, C.; ANDRADA, M.M.C. Limites críticos de densidade do solo para o crescimento de raízes de plantas de cobertura em Argissolo Vermelho. Revista Brasileira de Ciência do Solo, v.32, p. 1805-1816, 2008. DOI: dx.doi. org/10.1590/S0100-06832008000500002.
SALLES, N.; DANIEL, O.; HEID, D. M.; CARVALHO, R.P.; NOGUEIRA, I.M.B. Acúmulo de biomassa de Urochoa brizantha cv. Xaraés em sistema silvipastoril. Cadernos de Agroecologia, v.9, n.4, 2014.

SANTOS, F.R.P.; CASTILHO, R.M.M.; DUARTE, E.F. Caracterização físico-química de sete componentes de substratos recomendados para uso em floricultura. Cultura Agronômica, v.11, p.81-92, 2002.

SANTOS, P.L.F.; CASTILHO, R.M.M. Influência de diferentes substratos no teor de clorofila e massa fresca e massa seca em grama esmeralda. Técnologia e Ciência Agropecuária, v.10, n.6, p.1-5, 2016.

SARTAIN, J.B. Potassium requirement for tifway bermudagrass. Crop Science, v.42, n.4, p.507-512, 2002.

SCHREINER, H.G. Tolerância de quatro gramínea forrageiras a diferentes graus de sombreamento. Boletim de Pesquisa Florestal, n.15, p.61-72, 1987.

VERAS, V.S.; OLIVEIRA, M.E.; LACERDA, M.S.B.; CARVALHO, T.B.; ALVES, A.A. Produção de biomassa e estrutura do pasto de capim-andropogon em sistema silvipastoril e monocultura. Arquivo Brasileiro de Medicina Veterinária e Zootecnia, v.62, n.1, 2010. DOI: dx.doi.org/10.1590/S0102-09352010000100027.

VILLAS BÔAS, R.L.; GODOY, L.J.G. A produção de grama no Brasil e as pesquisas sobre nutrição e adubação de gramados na Faculdade de Ciências Agronômicas. Botucatu: FCA, 2006. 